\title{
United Kingdom Patent Decisions 2017
}

\author{
Julia Powles $\cdot$ John Liddicoat
}

Published online: 28 February 2018

(C) The Author(s) 2018. This article is an open access publication

\begin{abstract}
This report highlights the main UK patent decisions from 2017, including a major Supreme Court infringement case introducing a doctrine of equivalents, the first ruling on FRAND royalty rates and injunctions, compensation for employee inventors, legal priority, patentable subject matter, and a novel, unsuccessful attempt by the State to sue a pharmaceutical company whose invalid patents delayed the entry of generics.
\end{abstract}

Keywords Doctrine of equivalents · FRAND - Employee compensation · Infringement · Patent law · Priority

Cases Accord Healthcare Ltd v. Research Corp Technologies Inc [2017] EWHC 2711 (Ch); Actavis UK Ltd v. Eli Lilly \& Co [2014] 4 All E.R. 331; Actavis UK Ltd v. Eli Lilly \& Co [2016] 4 All E.R. 666; Actavis UK Ltd v. Eli Lilly \& Co [2018] 1 All E.R. 171; Actavis Group PTC EHF v. ICOS Corp [2017] EWCA Civ 1671; Ariosa Diagnostics Inc v. Sequenom Inc, 809 F.3d 1282 (Fed Cir, 2015); Arrow Genetics Ltd v. Merck \& Co Inc [2007] EWHC 1900 (Pat); Chugai Pharmaceutical Co Ltd v. UCB Pharma SA [2017] EWHC 1216 (Pat); Edwards Lifesciences AG v. Cook Biotech Inc [2009] EWHC 1304 (Pat); Fisher \& Paykel Healthcare Ltd $v$. ResMed Ltd [2017] EWHC 2748 (Ch); Fujifilm Kyowa Kirin Biologics Co Ltd v. AbbVie Biotechnology Ltd [2017] EWHC 395 (Pat); Generics (U.K.) Ltd (t/a Mylan) v. Yeda Research and Development Co Ltd [2017] EWHC 2629 (Pat); Illumnia Inc v. Premaitha Health Plc [2017] EWHC 2930 (Pat); Kirin-Amgen Inc v. Hoechst

\footnotetext{
J. Powles $(\bowtie)$

Research Fellow, New York University School of Law, Cornell Tech, New York, USA e-mail: julia.powles@nyu.edu

\section{J. Liddicoat}

Philomathia Postdoctoral Research Associate, University of Cambridge, Cambridge, UK e-mail: jel68@cam.ac.uk
} 
Marion Roussel Ltd (No. 2) [2005] 1 All E.R. 667; Les Laboratoires Servier v. Apotex Inc [2007] EWHC 1538 (Pat); Les Laboratoires Servier v. Apotex Inc [2008] EWCA Civ 445; Secretary of State for Health v. Servier Laboratories Ltd [2017] EWHC 2006 (Ch); Shanks v. Unilever Plc [2017] R.P.C. 15; Unwired Planet International Inc v. Huawei Technologies Co Ltd [2017] EWHC 711 (Pat); Unwired Planet International Inc v. Huawei Technologies Co Ltd [2017] EWHC 1304 (Pat).

Legislation Intellectual Property (Unjustified Threats) Act 2017; Patents Act 1977 (UK).

The most important UK patent decision of 2017 was the Supreme Court's monumental ruling on claim construction and scope in Actavis UK Ltd v. Eli Lilly \& Co. ${ }^{1}$ The case originated in a battle over whether Eli Lilly's patent to pemetrexed disodium for cancer treatment was infringed by Actavis' pemetrexed formulations. Eli Lilly was unsuccessful in the Patents Court, ${ }^{2}$ partly successful in the Court of Appeal, ${ }^{3}$ and successful in the Supreme Court. The reasoning, articulated by Lord Neuberger in one of his last judgments as President of the Supreme Court before retiring in September 2017, is of lasting import.

Dramatically, the Supreme Court dismissed the approach to claim construction that had prevailed in infringement cases since $2004,{ }^{4}$ in which what matters is what the person skilled in the art would have understood the language in the claims to mean (so-called "purposive construction"). Instead, relying on the Protocol to Art. 69 of the European Patent Convention, Lord Neuberger introduced a two-limb infringement test: first, querying whether there is infringement as a matter of "normal" or "literal" interpretation; and, second, applying a three-part "doctrine of equivalents", as is more familiar in Germany and the United States. Applying the test, the Court found that although Actavis' pemetrexed formulations did not fall within the literal meaning of the claims, they were "variants" or "equivalents" they "achieved substantially the same result in substantially the same way as the invention" (a concept the Court equated, problematically, with the shape-shifting notion of the "inventive concept"). Further, satisfying the second and third parts of the doctrine, the substantial equivalence of Actavis' formulations would have been obvious to a person skilled in the art, and the patentee would not have intended strict compliance with the literal meaning of the claims as an essential requirement of the invention. As a result, Actavis was found to have infringed the patent.

The new doctrine of equivalents has already been applied in several infringement cases. Both Generics (U.K.) Ltd (t/a Mylan) v. Yeda Research and Development Co $L t d^{5}$ and Illumnia Inc v. Premaitha Health Plc ${ }^{6}$ addressed the confusion caused by Lord Neuberger's choice of the word "literal" in the first limb of the test, with both Courts holding that it still means "purposive". Actavis v. Lilly nevertheless clearly

\footnotetext{
${ }^{1}$ [2018] 1 All E.R. 171; see IIC 49(1):104-105 (2018), https://doi.org/10.1007/s40319-017-0665-z.

2 [2014] 4 All E.R. 331.

${ }^{3}$ [2016] 4 All E.R. 666; see IIC 47(2):189 (2016), https://doi.org/10.1007/s40319-016-0457-x.

${ }^{4}$ Kirin-Amgen Inc v. Hoechst Marion Roussel Ltd (No. 2) [2005] 1 All E.R. 667.

5 [2017] EWHC 2629 (Pat).

${ }^{6}$ [2017] EWHC 2930 (Pat).
} 
rejects a one-stage purposive construction test, prompting the useful suggestion in Fisher \& Paykel Healthcare Ltd v. ResMed Ltd ${ }^{7}$ that the doctrine of equivalents be referred to as an approach to claim scope, rather than claim construction. Following Generics v. Yeda and Actavis Group PTC EHF v. ICOS Corp, ${ }^{8}$ it seems the test is confined to the infringement context, with the courts presently unwilling to extend it to novelty.

The second major claim construction issue in Actavis v. Eli Lilly was the relevance of the documented prosecution history (or, more colourfully, the "file wrapper"). During patent prosecution, Eli Lilly attempted to claim pemetrexed as a free acid. The patent examiner objected to this claim because it introduced subject matter beyond the contents of the original filing. As a result, Eli Lilly only claimed pemetrexed disodium. Seizing this concession, Actavis argued that since Eli Lilly confined its claim to a particular pemetrexed salt, this should mean that Actavis' formulations across a broader range could not infringe. Lord Neuberger rejected this argument, elaborating that UK courts should approach prosecution history with a "sceptical, but not absolutist attitude". He stated that, as a general rule, a patent's meaning should not depend on access to the prosecution history, but exceptions could arise in certain limited scenarios, including if the specification or claims are unclear and the file unambiguously resolves the issue, or where it would be contrary to public interest to ignore it. Ultimately, the prosecution history had no bearing on infringement in Actavis v. Eli Lilly itself, but future litigants may be able to avail themselves of the exceptions articulated in the judgment.

The long-awaited first instance decision in Unwired Planet International Inc $v$. Huawei Technologies Co $\mathrm{Ltd}^{9}$ was the first case to determine a FRAND (fair, reasonable and non-discriminatory) royalty rate. FRAND terms arise when a patent is essential to international standards; a situation that is particularly common in the telecommunications industry. To reduce friction or "hold-up" in accessing these patents, parties are obliged to accept FRAND licence terms. But what is a FRAND rate? Birss $\mathrm{J}$ held that it is determined by making adjustments (taking account of particular circumstances, region, etc.) to a "benchmark rate" that in turn comes from counting and weighting patents within the patentee's portfolio. In a lengthy application of these principles, Birss $\mathrm{J}$ found that Huawei was seeking a UK licence that was not FRAND, and that it had failed to consider a worldwide licence that was FRAND. He also found that FRAND licences and competition law are not coextensive, holding that a licence may be higher than FRAND and still not be anticompetitive. On injunctions, Birss $J$ stated that if a party needing to use a patent does not comply with a FRAND licence, then an injunction can be issued against them. He refrained from granting one in this instance, instead allowing Huawei to engage with the worldwide licence proposed by Unwired. In a subsequent decision, ${ }^{10}$ however, after Huawei had not given an unqualified undertaking to accept a worldwide licence on FRAND terms, Birss $J$ granted what he called a

\footnotetext{
7 [2017] EWHC $2748(\mathrm{Ch})$.

8 [2017] EWCA Civ 1671.

9 [2017] EWHC 711 (Pat).

${ }^{10}$ [2017] EWHC 1304 (Pat).
} 
"FRAND injunction" (stayed pending appeal), noting that it differs from a regular injunction because it includes the proviso that it will cease to have effect if, among other possibilities, the defendant enters into the FRAND licence.

Another highly anticipated case was the trial in Fujifilm Kyowa Kirin Biologics Co Ltd v. AbbVie Biotechnology Ltd. ${ }^{11}$ With its rights over the blockbuster autoimmune drug adalimumab (branded Humira) due to expire in October 2018, AbbVie had applied for numerous divisional patents to extend its protection. Fujifilm, trying to clear the path for its generic, ran an argument that its own dosing regimens on adalimumab were old or obvious and, as a result, should be able to be marketed without infringing AbbVie's patents. In a landmark decision, Henry Carr J agreed, declaring that Fujifilm's generic was anticipated or obvious. It is important to note, though, that he only made the declaration due to several "special reasons" on the "most unusual facts": AbbVie had threatened litigation but abandoned its proceedings at the last moment, while keeping its pending divisionals in play; Fujifilm had a lot of money at stake in progressing its generic to market; and Fujifilm needed commercial certainty from AbbVie's threats to sue. Though Fujifilm was inspired by the eponymous "Arrow declaration" granted in Arrow Genetics Ltd v. Merck \& Co Inc, ${ }^{12}$ Henry Carr J was careful to distinguish the purposes of the declarations in the two cases.

The Court of Appeal decided Shanks v. Unilever Plc, ${ }^{13}$ an important case on compensation for employee inventors - a process triggered in the UK if an employee's patent is of "outstanding benefit" to an employer. Though Professor Shanks' patent had netted tens of millions of pounds for his employer Unilever, the Comptroller and Patents Court denied that it produced an "outstanding benefit", ${ }^{14}$ primarily because Unilever was a large organisation with a huge turnover (as Shanks pithily critiqued it: "too big to pay"). The Court of Appeal agreed. Recognising that "outstanding benefit" is a relative concept that must be measured against the economic and business realities of the employer, the Court resisted an absolute assessment of the patent's value against some threshold of the employer's profits, while accepting that such a comparison is informative, particularly for smaller employers. The Court also clarified that the profit generated by a patent is what matters - not how the employer subsequently uses that profit.

The question of when a patent applicant can claim priority to an earlier application arose in several cases. Since Edwards Lifesciences AG v. Cook Biotech Inc ${ }^{15}$ it has been clear an applicant is only able to claim priority to an application filed by a third party if the applicant owned substantive rights to it at the time of filing. Based on this, in Accord Healthcare Ltd v. Research Corp Technologies Inc ${ }^{16}$ Accord argued that RCT (a technology transfer entity working with the inventor's university) could not claim priority to a US patent because a procedural

\footnotetext{
${ }^{11}$ [2017] EWHC 395 (Pat); see IIC 48(6):728 (2017), https://doi.org/10.1007/s40319-017-0625-7.

12 [2007] EWHC 1900 (Pat).

${ }^{13}$ [2017] R.P.C. 15; see IIC 48(4):466-467 (2017), https://doi.org/10.1007/s40319-017-0592-z.

${ }^{14}$ [2014] R.P.C. 29; see 46 IIC 221 (2015); https://doi.org/10.1007/s40319-015-0308-1.

15 [2009] EWHC 1304 (Pat).

${ }^{16}$ [2017] EWHC $2711(\mathrm{Ch})$.
} 
error meant it had only been transferred the bare legal title, not the substantive right. Referring to US law on bona fide purchasers for value, Birss J found that substantive title had in fact been transferred and, therefore, the priority claim was valid. At the same time, though, he noted inconsistencies in the law, especially with regard to equitable interests that are perfected only after a patent is filed, and made tentative suggestions as to how the law might be amended. Issues of legal priority also came up in Fujifilm v. AbbVie ${ }^{17}$ and in Actavis v. ICOS, ${ }^{18}$ with the courts in all three cases indicating an unwillingness to be drawn into protracted battles on priority.

Chugai Pharmaceutical Co Ltd v. UCB Pharma $S A^{19}$ was an interesting case involving foreign patents. The dispute concerned whether Chugai had to continue paying royalties under a worldwide licence that listed England in its governing law clause. Under this licence, Chugai manufactured and sold tocilizumab products in the US that were protected by several of UCB's US patents. Since 2016, however, all but one of the patents had expired, and Chugai argued the product actually fell outside the one remaining patent. When rival interpretations of patent scope arose during the Patents Court hearing, UCB complained that this indicated that the validity of a US patent was a substantive element of the case and, therefore, the dispute was non-justiciable because only US courts can rule on the validity of US patents. After careful study, Henry Carr J disagreed, concluding that the substance of the action concerned construction not validity and, as a result, the Patents Court had jurisdiction.

Illumina $v$. Premaitha ${ }^{20}$ concerned almost every substantive area of patent law, but one in particular stands out. A question arose as to whether a broad method for non-invasive prenatal genetic testing was a "discovery as such", precluding it from being patent-eligible subject matter. In the US equivalent of this case, ${ }^{21}$ the Federal Circuit en banc found the patent invalid on a similar basis. In the UK, however, Henry Carr J made short work of the "discovery as such" argument. The patented method was directed to the detection of DNA in a sample of plasma. Since neither the samples (an artificial creation) nor the method (an artificial process, practically applying a discovery) exist in the natural world, he found that the method was patentable.

An interesting set of cases is being argued in competition law and tort law as retribution for the invalidation - a decade ago, now - of Servier's controversial patents on perindopril for treatment of hypertension and cardiac insufficiency. ${ }^{22}$ In Secretary of State for Health v. Servier Laboratories Ltd, ${ }^{23}$ the Health Secretary tried to run a claim in tort that Servier should be responsible for causing loss by unlawful means, because it knew or was reckless as to the invalidity of its patents at

\footnotetext{
${ }_{17}$ Supra note 11.

18 Supra note 8.

19 [2017] EWHC 1216 (Pat).

${ }^{20}$ Supra note 6.

${ }^{21}$ Ariosa Diagnostics Inc v. Sequenom Inc, 809 F.3d 1282 (Fed Cir, 2015).

${ }^{22}$ Les Laboratoires Servier v. Apotex Inc [2007] EWHC 1538 (Pat); affirmed on appeal [2008] EWCA Civ 445.

23 [2017] EWHC 2006 (Ch).
} 
the time it was dealing with the EPO and UK courts, and its misrepresentations delayed the entry of generic perindopril manufacturers. Roth $\mathrm{J}$ rejected this argument, noting how disruptive it would be if such claims could be made against patentees.

Legislatively, the Intellectual Property (Unjustified Threats) Act 2017 came into force on 1 October 2017, and applies to all patentee communications on or after that date. Among other things, the Act introduces the concept of "permitted communications", which includes giving notice that a patent exists but not, for example, requesting that a person give an undertaking. Unjustified threats have been a nettlesome topic in recent times, and the Act is designed to create a clearer, harmonised framework for addressing threats across patent and other IP regimes, particularly trade marks and designs.

Open Access This article is distributed under the terms of the Creative Commons Attribution 4.0 International License (http://creativecommons.org/licenses/by/4.0/), which permits unrestricted use, distribution, and reproduction in any medium, provided you give appropriate credit to the original author(s) and the source, provide a link to the Creative Commons license, and indicate if changes were made. 